PROBLEMS

OF MANAGEMENT

IN THE $21^{\text {st }}$ CENTURY

Vol. 14, No. 1, 2019

\title{
WHEN PUBLIC MANAGING FAILS. THE HOUSING QUESTION IN EUROPE
}

\author{
Luca Bussotti \\ Federal University of Pernambuco, Brazil \\ International Studies Centre of ISCTE-IUL, Portugal \\ E-mail: luca.bussotti@iscte-iul.pt
}

If one seeks to rent a house for spending some months in a European city, or just some days on holiday, an aspect becomes immediately clear: the quasi-monopoly of an on-line platform, which proposes interesting and innovative solutions, from an entire apartment to a single room.

This on-line platform is Airbnb, created in 2007 in San Francisco and which in 2009 assumed the current denomination. Airbnb operates in 200 countries and about 8.100 cities, launching 5 million announcements yearly and hosting - through its associated structures about 300 million people per year (Rubino, 2018), having reached in 2018 the target of 500 million people (AIRBNB, 2019).

In economic terms, many hosts have been able to improve their revenue thanks to their association to Airbnb. It has been calculated that the revenue for 2017 reached by the company was $\$ 2.6$ billion, with $\$ 93$ million in profit (Zalesky, 2018). The hosts would have earned $\$ 65$ billion (Airbnb, 2019), obtaining important supplementary revenues from their previously unoccupied apartments. At the same time, many guests have experienced different ways of spending their holidays, making them feel involved in an "alternative" and intelligent tourism.

There is a vast array of opinions on Airbnb, its economic and social impacts and its influence on the crisis of low level hotels. Nevertheless, the expansion of Airbnb is not only related to the tourism sector, but also to the reconfiguration of historical and touristic cities and with the additional availability of rentals for low-income groups. With a result: those who already lived in good conditions and owned apartments in touristic cities have become even richer, while low-income groups have tended to be expulsed from the core of the cities where they lived, being forced to rent a house outside the urban context.

But let's go step by step...

Airbnb is not the main cause of the current situation of housing in Europe. It is just the most visible effect of a political conception which has left to the free market the role of regulating the match between housing supply and demand; this has been the prevalent tendency at least in the last 30 years in European politics for housing (Visalli, 2019). It is worth remembering that in this specific sector the main competences are in the hands of national States and for some aspects, single municipalities.

The logic of a subject such as Airbnb - or Uber, in the transport sector - is very simple: it is necessary to exploit and put in value on all personal belongings, in order to produce complementary incomes. House and car represent the last frontier of this new economic vision. For the success of this extreme attempt to give value to all personal belongings, public authorities have to share the same vision of Airbnb or Uber: no ethics or legal constraints should limit the action of the free market.

So, the two main questions which this short reflection intends to propose are the following: how has Airbnb contributed to the worsening of an already critical situation of housing in Europe? And how have European public authorities managed this new situation?

In order to answer these questions, it is necessary firstly to analyse the roots of the Airb$\mathrm{nb}$ commercial proposal, and question it using some data derived from recent, empirical studies. 
The philosophy of economic entities such as Airbnb and Uber is not of a speculative kind; on the contrary, starting from a win-to-win logic, they stand for a "shared economy". In the case of Airbnb it means essentially to embed a human relations approach into business. Brian Chesky, one of the founders and CEO of Airbnb, makes a clear distinction between the philosophy of Airbnb and normal, commercial logic: "For so long, people thought Airbnb was about renting houses. But really, we're about home". And here he explains the philosophical difference between Airbnb and every other kind of accommodation: "You see, a house is just a space but a home is where you belong". And concludes emphasizing that "This is the idea at the core of our company: belonging" (Chesky, 2014).

Around this basic idea of belonging, Airbnb has built its identity, becoming attractive as much for the host as for the guest. Chesky states that Airbnb intends to recover that lost sense of trust and belonging which featured in European human relations before the advent of the industrial revolution, thanks to the tools new technologies available. For, "Airbnb is returning us to a place where everyone can feel they belong". Chesky invented a symbol (Belò, which became the graphic brand of Airbnb), resuming the feeling of belonging, sharing community and trust. Airbnb expresses at the same time the main principles of shared economy, accentuating the freedom of the host ("Your space, your rules") as the appreciation for the guest ("the desire to feel welcomed, respected and appreciated for who you are"). Initially, Airbnb aimed at concentrating its network of accommodation on exploring untraditional touristic destinations, in order to induce people to discover different and amazing places. This was the reason why, in a first phase, the impact on hotels and on market housing was not so harsh as it has been in a second phase.

Since Airbnb is in permanent evolution and adaptation, it has promoted, in the past few years, a policy focused on collaborative and responsible consumption, sustainability, struggle against discrimination of ethnic and sexual minorities, reputation of hosts and guests, with mechanisms of "peer-to-peer-based activity of obtaining, giving, or sharing access to goods and services, coordinated through community-based online services" (Hamari, Sjöklint, \& Ukkonen, 2016; 2015). A transparent community based on human relations focused on belonging and common ethical principles which goes further than the simple market mechanism of hotel or house rentals: this has been the key for the success of Airbnb.

This is the story as told by Airbnb.

Nevertheless, there are at least two questions to examine: first, have the philosophical principles of belonging, community and a new way to explore touristic destinations been applied in practice by Airbnb? Second, what impact has Airbnb had on the reconfiguration of the rentals market in the main European urban centres?

Some empirical research carried out in both Europe and the United States can answer the first question. In London, the company has operated in an unregulated context, so "a lot of demand for short-term rentals comes from touristic areas (...) and so traditional regulations are unlikely to be able to respond to those changes" (Quattroni et al, 2016). The overlapping of Airbnb accommodations with traditional structures, primarily hotels concentrated in the centre of urban cities, has been reported in many other European countries: in Italy, the third country after United States and France in terms of spreading of Airbnb accommodations, $62.2 \%$ of the announcements come from people who manage them through a pure market-oriented logic. Host and guest never will meet each other in these houses $(76.6 \%$ of the announcements refer to uninhabited houses), so that one of the basic principles of the shared economy is not applied. Brokers, in Italy, manage up to 4000 units, according to Federalberghi (Montrella, 2019), and $64.5 \%$ of the accommodations associated to Airbnb in Italy are usually rented for more than 6 months to a year. Even if some research expresses a certain caution in reaching these conclusions (Coyl \& Yu-Chong Yung, 2016), it seems that the prevalent conclusion is that the activity of the host related to Airbnb is, in many cases, a principal economic activity, a job, and not a simple income supplement..

PROBLEMS

OF MANAGEMENT

IN THE $21^{\text {st }}$ CENTURY

Vol. 14, No. 1, 2019 
PROBLEMS

OF MANAGEMENT

IN THE $21^{\text {st }}$ CENTURY

Vol. 14 , No. 1,2019

The other consequence of the overlapping between Airbnb structures and traditional hotels in the most touristic cities in Europe is that, firstly, the philosophy of experiencing a different tourism does not exist and, secondly, the low-level hotels have tended to disappear. Yet in Italy, in 2018, the accommodations associated to Airbnb have reached the considerable number of 397.314 units, with an increment of 78.3\% in relation to 2016. This "shadow economy" operated for many years (and in part until today) in a regime of unfair competition with the hotels, due essentially to the fact that they did not pay taxes, different from the hotels, which were submitted to about $50 \%$ of taxation on their revenues. Today, in Italy, there is a generous flat tax of 21\%, according to the Law Decree 50/2017 (Montrella, 2019).

Some researchers called the changes brought about by Airbnb a "disruptive innovation", instead of "shared economy" (Guettang, 2015), alluding to the reconfiguration of historical centres of the main European cities (Gutiérrez, 2017). The lack of planning by public entities regarding the housing market helped the hosts associated to Airbnb to expand their supply of accommodations. In Italy, since 1993, 190.000 habitational units have been sold at very convenient prices by public authorities, reducing by $22 \%$ the public real estate and providing members of the middle and upper-classes a chance to buy these units, using a great part of them for short-term rentals (Romito, 2019).

Not only in Italy, where social housing is residual (3.7\% of the total housing market), but all over the Europe the trend is the same, also in countries as Germany and UK, where public housing still represents about $17 \%$ of the total amount of its national real estate.

This point opens the doors to another important question: what is the impact of Airbnb on the rental market in Europe, with a particular focus on social housing? Although it is not always possible to identify a direct relation between Airbnb activity and growing lack of social housing, some data reveal a clear trend.

In Germany, the market tendency shows a willingness by public authorities to sell habitational units, which institutional investors are eager to buy. The result is that these units enter the free market, privileging the Airbnb logic of short-term rentals, to the detriment of more traditional forms, directed towards low-income families. In Cologne, between 2010 and 2019, the price of rent increased 40\%, in Dresden 30\%; Brussels registered the most significant increasing of the houses prices since 2009, meanwhile in all European countries, with the exception of Finland, a rise of homeless, largely due to the lack of social housing, has been registered $(\mathrm{Hu}, 2017)$. In the last few years the number of homeless has increased 50\% in France, 23\% in Denmark, 24\% in Netherland (IDEM). Consequently, a large segment of the population has been expelled from the urban centres, looking for a social housing at the outskirts of the towns, generally without success (OECD, 2016).

As Housing Europe reports, "the spreading of Airbnb and other on-line platforms for short rentals has significantly contributed to increasing this practice in recent years", so that Airbnb has exacerbated "the situation in cities with an already very tense housing market" (Hu, 2017: 32).

Before the accumulated phenomena of the retreat of public authorities from the regulation of housing market, the disposal of public assets and the consequent acquisition of habitational units by institutional investors, the penetration of Airbnb has accentuated old structural fragilities.

Civil society and some municipalities have tried to organize forms of resistance, proposing (partial) solutions. From the point of view of municipalities, it is worth remembering an initiative carried out by eight European cities, which, in 2018, wrote a letter to the EU Commission seeking ways to regulate on-line platforms, such as Airbnb and Booking.com. This movement was led by Amsterdam and its deputy mayor, Laurens Ivens. The movement demanded that Airbnb and Booking.com share data with local municipalities, with the involvement of EU authorities, given the European General Data Protection Regulation, which regulates the access 
to private data by public authorities. It also requested strict control of the activity of these online platforms, as much for protecting the local housing market, as for avoiding "the constant noise of suitcase wheels on the pavement outside". The loss of the traditional "sense of community" because of the episodic occupation of habitational units is another important factor, Laurens Ivens pointed out (Amsterdam, 2018).

At the same time, many European tourist cities have adopted restrictions to the shortterm rentals promoted by establishments such as Airbnb. The same Amsterdam, together with Barcelona and Madrid, ceased renting flats by Airbnb during events particularly attractive for tourists, for instance during the year of LGBT Pride Month (Betancourt, 2018). And for the first time, Palma de Mallorca prohibited short-term rentals through platforms such as Airbnb.

This regulation by municipalities had to do especially with the length of the rental: for instance, Amsterdam decided that an apartment on the Airbnb network could not be rented for more than 30 days a year, Atenas for 90, Barcelona for 120, but with the obligation for the owner to reside on site of the rented unit, Paris for 120, but with the obligation of public registry, and so on.

From the side of civil society, many movements are trying to revert a very difficult scenario of housing rentals all over the Europe. A first movement which demanded the right to housing began in Germany, the European country with the most consolidated tradition in this field. Jacobin - this is the name of this social movement - started in Berlin, but immediately spread to other German cities, such as Cologne and Dresden. In parallel, similar movements affirmed their action in other European countries and cities: in London it was the Radical Housing Network, in Paris the Droit au Logement, and so on. The main concern of all these movements is the right to housing for all, associated with the struggle for reasonable rental prices. Consequently, these movements are trying to stop the penetration of businesses such as Airbnb into the main European cities, since these are considered to be co-responsible for the decreasing of availability of houses for long-term rentals for residents, as well as rental increases.

It is difficult to say towards which direction the housing market will tend in Europe. What is certain is that if public authorities do not take a clear position with respect to planning and regulating powerful entities such as Airbnb, the processes here described will continue to characterize European cities, transforming them in what Zuenir Ventura has called a "cidade partida" ("divided city"), with reference to Rio de Janeiro (Ventura, 1994).

\section{Acknowledgement}

The author would like to thank Sidney Pratt for her linguistic revision.

\section{References}

Airbnb (2019). Airbnb celebrates half a billion guest arrivals. Retrieved from: https://press.airbnb.com. Amsterdam, other EU cities, urge Brussels to take action on Airbnb data. DutchNews.nl, 26/01/2018. Retrieved from: www.dutchnews.nl.

Betancourt, S. C. (2018). Some European cities turn against Airbnb during the height of tourist season, 6/6/2018. Online Marketplace. Retrieved from: https://www.onlinemarketplaces.com/ articles/20230-some-european-cities-turn-against-airbnb-during-the-height-of-tourist-season.

Chesky, B. (2014). Belong anywhere. Retrieved from: https://medium.com/@bchesky/belong-anywhereccf42702d010

Coyle, D., \& Yu-Cheong Yeung, T. (2016). Understanding Aibnb in fourteen European cities. Toulose: Working Paper of the Toulose School of Economics. Retrieved from: http://www.tse-fr.eu.

Gutiérrez, J., Garcia-Palomares, J. C., Romanillos, G., \& Salas-Olmedo, M. H. (2017). The eruption of Airbnb in tourist cities: Comparing spatial patterns of hotels and peer-to-peer accommodation in Barcelona. Tourism Management, 62, 278-291. 
Luca BUSSOTTI. When public managing fails. The housing question in Europe

PROBLEMS

OF MANAGEMENT

IN THE $21^{\text {st }}$ CENTURY

Vol. 14 , No. 1, 2019

Guttentag, D. (2016). Airbnb: Disruptive innovation and the rise of an informal tourism accommodation sector. Current Issues in Tourism, 18(12), 1192-1217.

Hamari, J., Sjöklint, M., \& Ukkonen, A. (2016). The sharing economy: Why people participate in collaborative consumption. Journal of the Association for Information Science and Technology, 67(9), 2047-2059.

Housing Europe (2017). The State of House in the EU. Brussels: Housing Europe.

Montrella, S. (2019). Airbnb sta uccidendo gli alberghi? Un'inchiesta [Is Airbnb killing hotels?]. Retrieved from: http://www.agi.it/economia/airbnb_alberghi_5304957/news/2019-04-12.

OECD (2016). Affordable housing database. Retrieved from: www.oecd.org.

Quattroni, G., Proserpio, D., Quercia, D., Capra, L., \& Musolesi, M. (2016). Who benefits form the "Sharing" Economy" of Airbnb? Retrieved from: https://.ucl.ac.uk/ ucfamus/papers/www16 airbnb.pdf.

Romito, S. (2019). In Italia la casa non è più un diritto. Il paradosso delle case popolari è un problema da risolvere [In Italy housing is no more a right. The paradox of social housing is an issue to be solved]. Retrieved from: http://thevision.com/architettura/case-popolari-diritto/.

Rubino, I. (2018). Affitti brevi e trasformazioni nelle aree urbane: il caso di Torino [Short rentals and transformations in urban areas: The case of Turin]. Territorio Italia, 1(5), 91-109. doi: 10.14609/ TI 118 5i.

Ventura, Z. (1994). Cidade partida [Divided city]. Rio de Janeiro: Companhia das Letras.

Visalli, A. (2019). Aufstehen e dintorni: campagna per il diritto alla casa [Aufstehen and surroundings: A campaign for the right of housing]. Retrived from: patriacostituzione.it/2019/03/31/aufstehene-dintorni-campagna-per-il-diritto-alla-casa/.

Zalesky, O. (2018). Inside Airbnb's battle to stay private. Bloomberg, 6/2/2018. Retrieved from: www. bloomberg.com.

Received: April 12, 2019

Accepted: June 29, 2019

$\mathrm{PhD}$ in Sociology of Development, Associate Visiting Professor at Federal University of Pernambuco and Researcher at ISCTE-IUL Lisbon, Rua Torres Homem, 633 Recife, Brazil.

E-mail: luca.bussotti@iscte-iul.pt 